Letter

\title{
Seismic evidence of glacial-age river incision into the Tahaa barrier reef, French Polynesia
}

\author{
Michael R. Toomey ${ }^{\mathrm{a}, \mathrm{b}, *}$, Jonathan D. Woodruff ${ }^{\mathrm{c}}$, Jeffrey P. Donnelly ${ }^{\mathrm{d}}$, Andrew D. Ashton ${ }^{\mathrm{d}}$, J. Taylor Perron ${ }^{\mathrm{e}}$ \\ a Eastern Geology and Paleoclimate Science Center, United States Geological Survey, Reston, VA 20192, USA \\ b Jackson School of Geosciences, University of Texas at Austin, Austin, TX 78712, USA \\ c Department of Geosciences, University of Massachusetts at Amherst, Amherst, MA 01003, USA \\ 'd Department of Geology E' Geophysics, Woods Hole Oceanographic Institution, Woods Hole, MA 02543, USA \\ e Department of Earth, Atmospheric, and Planetary Sciences, Massachusetts Institute of Technology, Cambridge, MA 02139, USA
}

\section{A R T I C L E I N F O}

\section{Article history:}

Received 13 October 2015

Received in revised form 5 April 2016

Accepted 7 April 2016

Available online 13 April 2016

\section{Keywords:}

Coral

Island

Lagoon

Dissolution

Morphology

\begin{abstract}
A B S T R A C T
Rivers have long been recognized for their ability to shape reef-bound volcanic islands. On the time-scale of glacial-interglacial sea-level cycles, fluvial incision of exposed barrier reef lagoons may compete with constructional coral growth to shape the coastal geomorphology of ocean islands. However, overprinting of Pleistocene landscapes by Holocene erosion or sedimentation has largely obscured the role lowstand river incision may have played in developing the deep lagoons typical of modern barrier reefs. Here we use high-resolution seismic imagery and core stratigraphy to examine how erosion and/or deposition by upland drainage networks has shaped coastal morphology on Tahaa, a barrier reef-bound island located along the Society Islands hotspot chain in French Polynesia. At Tahaa, we find that many channels, incised into the lagoon floor during Pleistocene sea-level lowstands, are located near the mouths of upstream terrestrial drainages. Steeper antecedent topography appears to have enhanced lowstand fluvial erosion along Tahaa's southwestern coast and maintained a deep pass. During highstands, upland drainages appear to contribute little sediment to refilling accommodation space in the lagoon. Rather, the flushing of fine carbonate sediment out of incised fluvial channels by storms and currents appears to have limited lagoonal infilling and further reinforced development of deep barrier reef lagoons during periods of highstand submersion.
\end{abstract}

Published by Elsevier B.V.

\section{Introduction}

The disappearance of hotspot islands as they age can be attributed to erosion (fluvial/marine) and subsidence (Darwin, 1842; Daly, 1910). Rapid subsidence occurs on young islands (up to $\sim 1$ Myr) as active volcanism loads the lithosphere but slows considerably following flexural compensation (Huppert et al., 2015), eventually approaching background thermal cooling rates (Detrick and Crough, 1978; Stein and Stein, 1992). Fluvial erosion and chemical weathering wear down most of the remaining volcanic edifice, reducing even large ocean islands to submarine banks, atolls or almost atolls in $10 \mathrm{Myr}$ (e.g., Chuuk, Caroline Islands: 8.4 Myr; Gambier, Pitcairn Chain: 6.2 Myr) (Dasgupta et al., 2010). However, the impact of sediment and freshwater delivery by upland drainage networks on the morphology of encircling

\footnotetext{
* Corresponding author at: Eastern Geology and Paleoclimate Science Center, United States Geological Survey, Mail Stop 926A, 12201 Sunrise Valley Drive, Reston, VA 20192, USA.

E-mail address: mtoomey@usgs.gov (M.R. Toomey).
}

reefs remains largely unexplored. Backfilling at deltas and deep passes, likely carved by rivers during sea-level lowstands (Fig. 1), are perhaps the most pervasive imprints of fluvial deposition and erosion on reefs, though some have argued that barrier reef morphology itself may be intimately linked to terrestrial drainage networks (Purdy and Winterer, 2006).

Makatea islands, which are similar in appearance to uplifted barrier reefs, have been proposed to be modern analogs for how fluvial incision can transform a fringing-reef-bound island into a barrier reef. Stoddart and others (Stoddart and Spencer, 1987; Stoddart et al., 1985) proposed a simple conceptual model for formation of makatea islands such as Mangaia, Cook Islands, where an uplifted ( $<73$ masl) fringing reef 'brim' surrounds the volcanic upland (Fig. 1A,B), obstructing the flow of streams cutting from the interior of the island (169 masl) to sea level: (1) Caves that perforate the uplifted reef accommodate normal streamflow; however, at peak discharge, water backs up at the inland contact between the volcanic basement and carbonate rim, enhancing local dissolution. (2) Over time, this erosional front forms steep cliffs along the landward edge of the uplifted reef (inland facing) which gradually advances seaward (Fig. 1A,B). On southeastern Guam, 

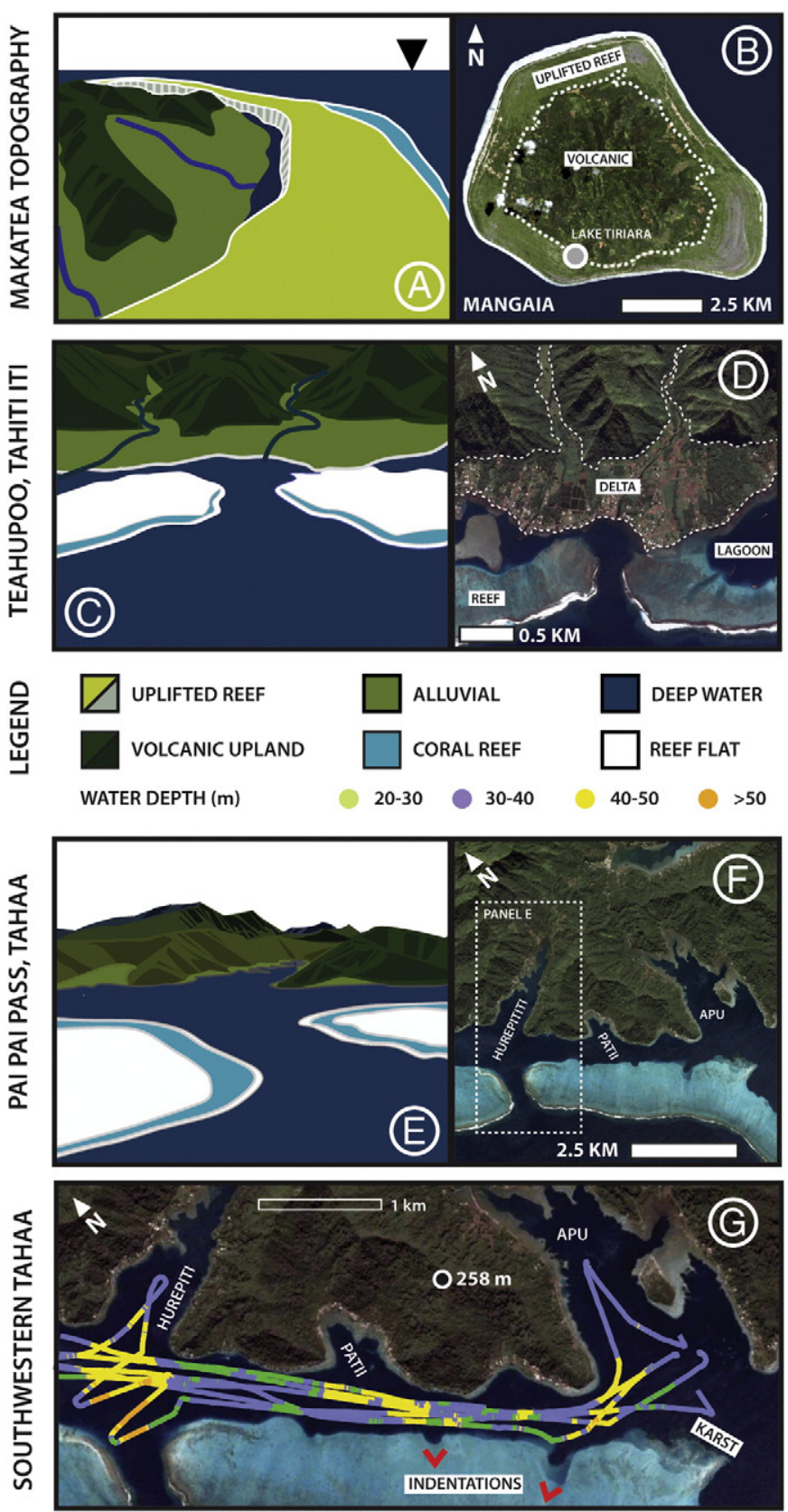

Fig. 1. Reef feature schematics and aerial imagery: (A, B) makatea topography on the island of Mangaia, Cook Islands. The moat between the carbonate rim and volcanic upland is thought to form from fluvial back-wearing following uplift of a predecessor fringing reef and possibly represents an analog to barrier reef formation during glacial lowstands. Lake Tiriara, Mangaia, a type locality for makatea formation, is shown by gray circle. Cliff-face is shown by vertical lines in panel A. (C, D) Fluvial deposition and erosion on young volcanic islands: Teahupoo, Tahiti Iti. (E, F) Mature, deep, reef pass: Pai Pai/Hurepiti, Tahaa. (G) Aerial view of Tahaa's southwestern lagoon overlain by bathymetry collected during this project. Red chevrons mark indentations to the seaward fringe of the barrier reef flat. Several indentations appear linked with lagoonal channels and upland drainage networks. Satellite imagery modified from Google Earth ${ }^{\mathrm{TM}}$.

Mariana Islands (e.g., Talofofo River) and Rurutu, Austral Islands, stream valleys often bisect raised carbonate margins (Stoddart and Spencer, 1987; Taborosi et al., 2005), having cut completely through uplifted reefs.

The same processes observed on uplifted carbonate islands may have contributed to the development of barrier reef morphology during sea-level lowstands. However, at present, the imprint of Pleistocene lowstand incision is largely obscured by transgressive flooding of barrier reef lagoons and subsequent deposition of Holocene sediments. Subbottom stratigraphy has been extensively mapped for only a few barrier reef settings, namely Mayotte in the Indian Ocean (Zinke et al., 2001) and New Caledonia in the southwest Pacific (Le Roy et al., 2008). Unlike the much smaller makatea islands of French Polynesia (typically $<5 \mathrm{~km}$ in radius), submerged channels in Nouméa Lagoon ( 10-20 km wide), New Caledonia, appear to propagate from the shelf edge and are decoupled from upland drainage networks (Le Roy et al., 2008). At Mayotte ( 7-15 km wide), empty-bucket morphology is attributed to low sedimentation and/or high-energy currents (Zinke et al., 2001), not fluvial erosion. Instead, lagoonal infilling by upland, fine-grained, siliciclastic material was observed in nearshore areas (Zinke et al., 2001).

In order to add to the still limited set of stratigraphic observations that document the role of fluvial incision and/or backfilling in governing the morphology of barrier reef-bound islands over glacial-interglacial sea-level cycles, we present seismic and core stratigraphy from Tahaa in the Society Islands, French Polynesia. We use these data to address two questions: (1) whether fluvial incision is an important mechanism for creating accommodation space in lagoons during glacial lowstands and/or (2) if rivers fill barrier reef lagoons with terrestrial sediment during highstands.

\section{Site description}

Tahaa $\left(16^{\circ} \mathrm{S}, 151^{\circ} \mathrm{W}\right.$, a.k.a. Taha'a) is an ocean island in the Society Islands (French Polynesia) hotspot chain located $225 \mathrm{~km} \mathrm{NW}$ of Tahiti, and $30 \mathrm{~km}$ SE of Bora Bora. Since the island formed 2-3 Myr ago (Guillou et al., 2005), fluvial drainage networks have incised the volcanic upland, leaving a dissected volcanic-island landscape (Fig. 2A,B). Much of this erosion was likely accomplished early in Tahaa's history - today, no perennial streams exist on the island likely owing in part to the high permeability typical of volcanic basements (Peterson, 1972 ) and strong seasonality of rainfall. Tahaa receives $\sim 2 \mathrm{~m} /$ year of precipitation (KNMI - http://climexp.knmi.nl/), much of it falling during the austral summer (DJF). The prevailing trade winds may also enhance rainfall on the eastern side of the island.

Tahaa and Raiatea (an island $6 \mathrm{~km}$ to the south) are encompassed by opposite ends of a common 'figure-eight' barrier reef (Davis, 1928) (Fig. 2C,D). This study focuses on the northern and southern sectors of Tahaa's western lagoon, which are separated by a submarine ridge $(<30 \mathrm{mbsl})$ near Tiva. At Tahaa, the reef provides a nearly continuous barrier between the lagoon and open ocean, except where it is cut by two deep passes, Pai Pai and Toahotu (Fig. 2D). These passes likely provide the main outflow pathway for water that enters the lagoon across the barrier reef or through shallow ( 100-400 m wide) channels (hoa, $\sim 2-3$ m deep) that bisect a series of low-lying islands (motu) along the northern extent of Tahaa's barrier reef, similar to hydrologic patterns recognized on nearby Bora Bora (Guilcher, 1969; Pirazzoli, 1985). Shallowly submerged, likely subaerially eroded, limestone (karst) near the mouth of Apu Bay $\left(16.6877^{\circ} \mathrm{S}, 151.4940^{\circ} \mathrm{W}\right.$; Fig. 1G) and elsewhere around Tahaa, indicates much of the barrier may be last interglacial or older in age.

\section{Materials and methods}

Seismic surveying of the western and northern sectors of the lagoon separating Tahaa (Apu Bay to Patio) from its encircling barrier reef was carried out aboard the S.S.V. Robert C. Seamans using a Benthos CHIRP-II $(2-7 \mathrm{kHz})$. Chirp settings (pulse rate, etc.) were calibrated on-site and reflector intersections were checked for consistency during postprocessing using Triton Imaging Inc., 2.0 Sub-Bottom Interpreter. A standard speed of sound through water $(1500 \mathrm{~m} / \mathrm{s})$ was used to calculate bathymetry. Channels were identified visually using seismic stratigraphy and satellite imagery (Google Earth ${ }^{\mathrm{TM}}$; CNES/Astrium). Upland 


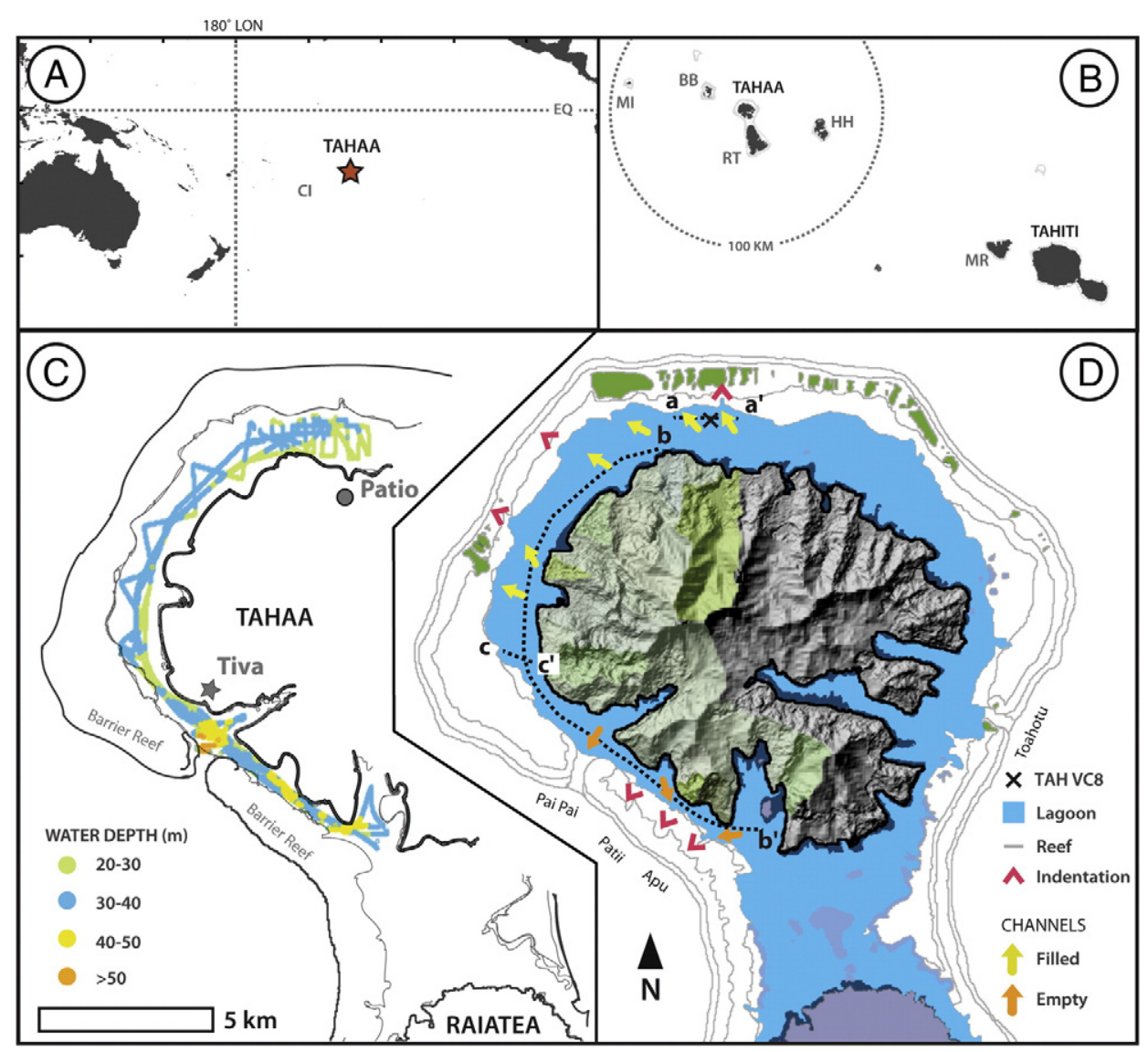

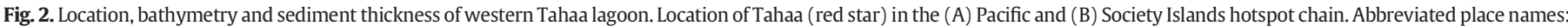

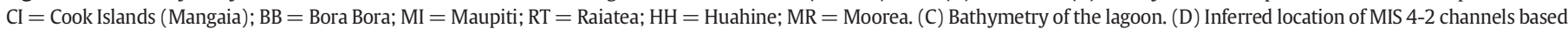

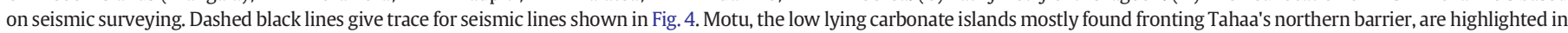

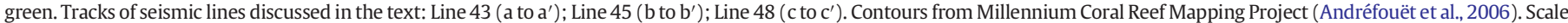
same as panel ' $C$ '.

watersheds were mapped using ArcMap10 (Esri) and digital elevation data (90-m resolution) from NASA's Shuttle Radar Topography Mission (SRTM 4.1).

Surface sampling and vibracoring were also carried out in order to ground-truth prominent features seen in the seismic stratigraphy. Vibracore TAH VC8 $\left(16.568^{\circ} \mathrm{S}, 151.502^{\circ} \mathrm{W}\right.$, Figs. 2D, 3) was taken to specifically target the shallowest, prominent subsurface reflector (Fig. 4A). Grain-size and geochemical (X-ray fluorescence, XRF) measurements were taken across prominent stratigraphic horizons in TAH VC8 in order constrain the depositional/erosional environments of observed seismic reflectors. Loss on ignition (Heiri et al., 2001) and X-ray diffraction (XRD) (e.g. Poppe et al., 2001) analyses were used to constrain the composition of an exposure horizon seen in TAH VC8. A companion core, TAH VC9 $\left(16.5678^{\circ} \mathrm{S}, 151.5041^{\circ} \mathrm{W}\right.$, Fig. 2D), was taken in a filled channel adjacent ( $200 \mathrm{~m}$ west) to TAH VC8. Chronologies for TAH VC8/9 were constrained using radiocarbon measurements from the National Ocean Sciences Accelerator Mass Spectrometry Facility (NOSAMS) in Woods Hole, Massachusetts. Carbonate samples were dated using continuous flow gas bench methods (Roberts et al., 2013). Organic carbon in basal samples from TAH VC8/9 was dated using conventional AMS techniques. Radiocarbon dates were calibrated using CALIB.7 (Reimer et al., 2013) with a standard marine correction (e.g., reservoir effect $\approx 400$ years) on the carbonate samples from TAH VC8 as well as marine organics $\left(\Delta^{13} \mathrm{C}=-16.6\right.$, Stuiver and Polach, 1977) in TAH VC9.

\section{Results}

Surface samples transecting the barrier reef and from the lagoon floor are primarily composed of sand-size detrital grains (e.g., coral fragments, Halimeda, shells) on the reef flat and fine-grain carbonate silt and mud (bio-eroded) in the lagoon, consistent with recent observations from Bora Bora (Gischler, 2011). Fine-grained terrestrial material (oxides/clays) is found in protected nearshore lagoon areas of Tahaa (e.g., Apu Bay) with transport of coarse-grained clastic material from the volcanic upland by overland flow likely only occurring during extreme storm events due to the high soil infiltration rates typical of volcanic slopes (e.g., Peterson, 1972).

Stratigraphic analysis of TAH VC8 (Fig. 3) suggests substantial depositional changes have occurred within Tahaa's lagoon since the last interglacial. The uppermost part of TAH VC8 is composed of fine-to-medium biogenic sand in a carbonate mud matrix. Grain size and shell content increase below $35 \mathrm{~cm}$, eventually transitioning $(160 \mathrm{~cm})$ to a rudstone dated to around $2.5 \mathrm{kyrs}$ BP in age. This rudstone is dominantly composed of large bivalve shells, razor coral and Halimeda fragments possibly representing a higherenergy depositional setting than present. The bottom unit (>196 cm) dates to $\sim 25$ kyrs BP (Table 1 ) and is composed of hard brown sediment with only a few macrofossils (e.g., shell fragments) in the upper part of this section, possibly entrained from above. Material larger than coarse-sized silt $(>32 \mu \mathrm{m})$ is extremely limited below $215 \mathrm{~cm}$ (Fig. 3) and consists of well- to sub-rounded volcanic clasts and sparse organics. XRD analysis of the basal unit indicates it is predominantly composed of Fe/Ti oxides (goethite, ilmenite, rutile) and clay (kaolinite). Unlike the Holocene lagoonal deposits of TAH VC9 $\left(\delta^{13} \mathrm{C}=-17 \%\right.$; marine organic carbon), the basal unit of TAH VC8 has a $\delta^{13} \mathrm{C}$ signature $\left(-25 \%\right.$ ) consistent with $C_{3}$ plants (e.g., trees) (Stuiver and Polach, 1977). With an organic content of $\sim 12 \%$, this clay unit is also considerably more organic-rich than 


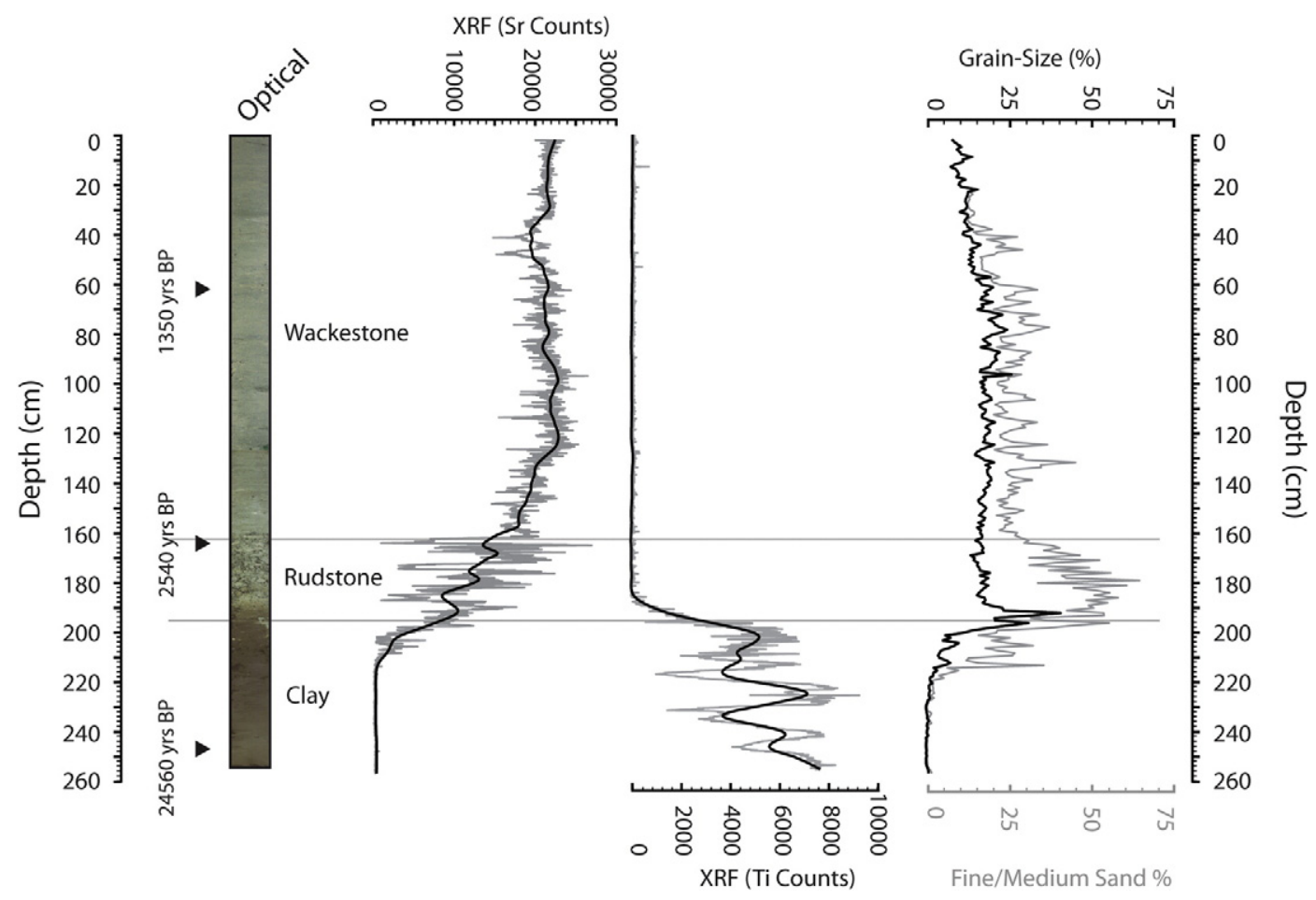

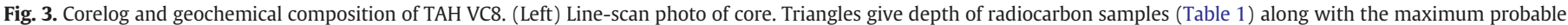

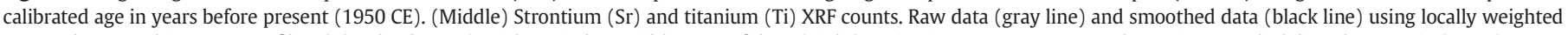

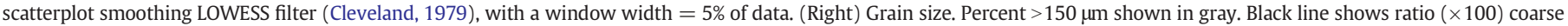
fraction $(1000-150 \mu \mathrm{m})$ to fine fraction $(<150 \mu \mathrm{m})$. Loss on ignition and XRD measurements were made on samples from 215 to $220 \mathrm{~cm}$ depth.

Holocene marine units ( $6 \%$ organic) even in nearshore areas such as Apu Bay.

Given that sea level (Lambeck and Chappell, 2001) is thought to have been below the current depth of the lagoon from at least $\sim 70$ kyrs BP up until the deglacial transgression ( $10 \mathrm{kyrs} B P)$, we interpret this unit as representing an exposure horizon/paleosol likely spanning the lowstand between Marine Isotope Stage (MIS) 5 and the Holocene. On Mangaia, potentially analogous clay deposits are found in the moat between the inland volcanic cone and uplifted carbonate brim, where eroded material from highland slopes was deposited in Holocene swamps (Ellison, 1994). TAH VC8 and other sedimentary sequences collected from Tahaa contain few volcanic clasts. This is in contrast to Tahiti, where a thick unit of terrestrial sands accumulated behind the barrier reef near Papeete as it grew during the last deglaciation (Cabioch et al., 1999). Given their absence, we hypothesize that most terrestrial weathering products are generally fine-grained or have been transported offshore into the open ocean. Dissolution of exposed lagoonal sediment from previous interglacials by rainwater, which likely contained trace amounts of oxides/clay, could also have contributed to development of the exposure horizon identified in TAH VC8.

Seismic surveying shows a layer-cake stratigraphy of at least four distinct depositional units, separated by similar subaerial horizons, underlying much of Tahaa's lagoon (Fig. 4). The uppermost sedimentary sequence can be directly correlated to the stratigraphy of TAH VC8. The shallowest reflector is the last glacial subaerial exposure surface and overlays sediments that have been deposited since deglacial flooding, most probably during the mid-late Holocene (Toomey et al., 2013). By analogy, the deeper stratigraphic units likely represent older interglacial deposits separated by exposure horizons similar to stratigraphic sequences documented elsewhere in the Pacific including: Enewetak Atoll, Marshall Islands (Wardlaw and Quinn, 1991), Funafuti Atoll, Tuvalu (Ohde et al., 2002), and Mururoa Atoll (Buigues, 1997; Camoin et al., 2001).

In general, seismic lines running shore-normal show a gradual slope with increasing Holocene sediment thickness approaching the reef barrier (seaward direction) (Fig. 4). Moving in the shore-parallel direction, the lagoon is crosscut by steeply-sided channels resulting in more variable bathymetry (Fig. 4). Hard, coarse-grained, bottoms are indicated by strong seismic reflection within these channels. Several generations of channel fill deposits indicate channel development has likely persisted over successive glacial-interglacial cycles. Many channels appear to originate at the mouth of embayed valleys, the deepest (>50 mbsl) of which extends from Hurepiti Bay through Pai Pai pass, bisecting the barrier. Other channels (e.g., Patii, Apu) appear to terminate at the back edge of the barrier, and in many cases indent it (Fig. 1G).

\section{Discussion}

Key differences in channel geometry moving from the north (small and sediment filled) to south (large and empty) of Tahaa's lagoon could result from two main factors: (1) steeper antecedent topography along the southern flank of the island and (2) storm flushing of fine sediment out of Pai Pai pass. Each is discussed in more detail below. Spatial differences in upland drainage size, like those noted for Tahiti (Purdy and Winterer, 2006), are also thought to impact lagoon incision during lowstands; however, western Tahaa catchments are, in general, relatively similar in size to each other.

Gentle antecedent slopes along Tahaa's northwest coast may have promoted gradual progradation of the barrier offshore over the past 2-3 million years. The evidence of this is seen in the modern geometry of the lagoon. In general, the coast of the volcanic island and landward edge of the reef flat are separated by a linear distance perpendicular to the volcanic shoreline of less than $1 \mathrm{~km}$ south of Tiva compared with almost $2 \mathrm{~km}$ near Patio on the north side of the island. Due to the high porosity typical of unconsolidated carbonate sediments, upland flow may have infiltrated rapidly across a wide exposed barrier reef lagoon, limiting back-wearing of the barrier and, ultimately, formation of reef passes along Tahaa's northwestern coast. In contrast, a narrow or non-existent lagoon, such as that along Raiatea's western coast ( 4 passes, $>10$ 

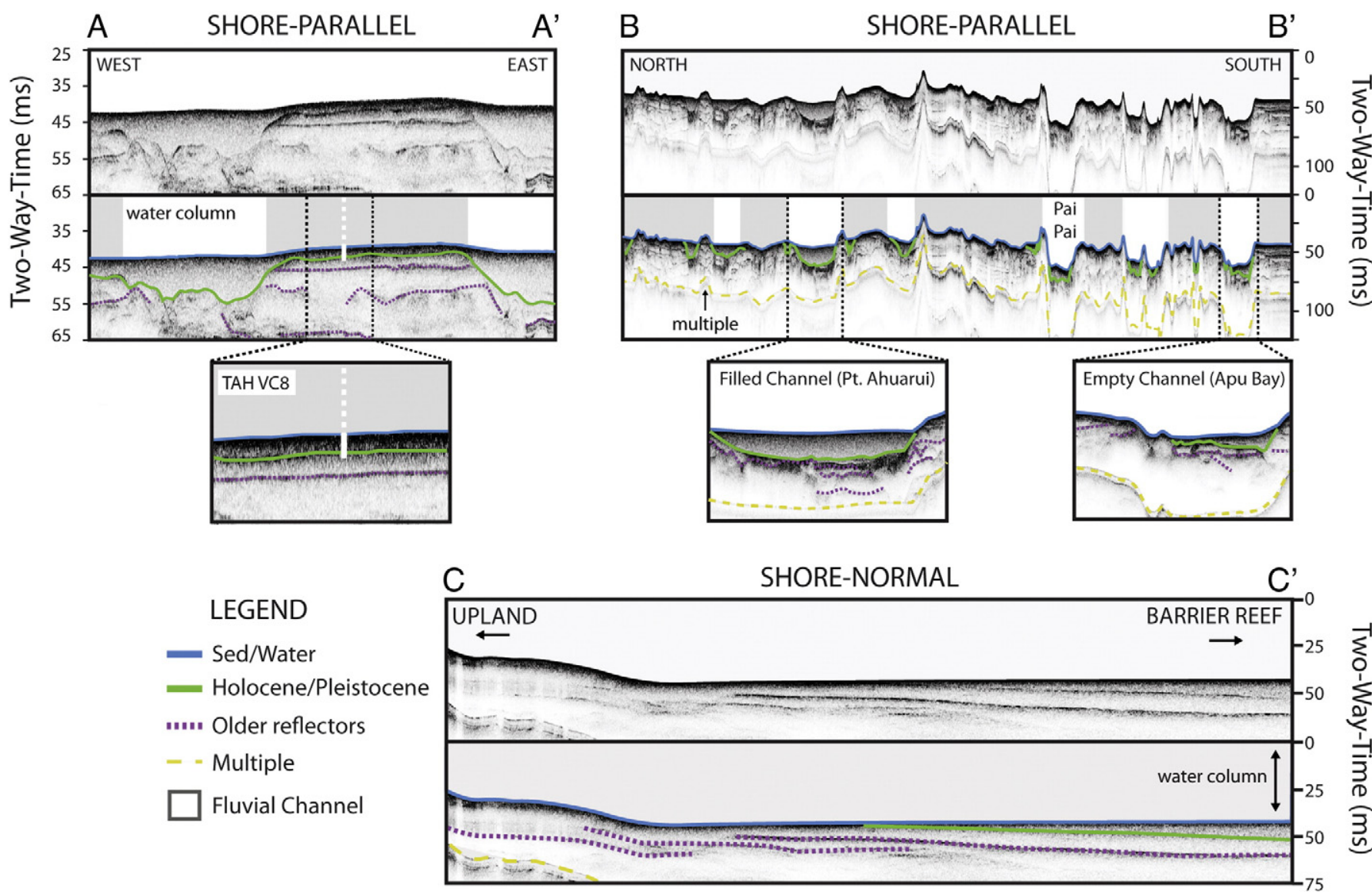

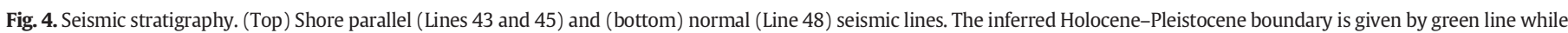

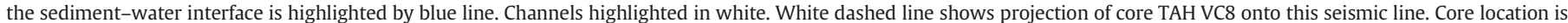

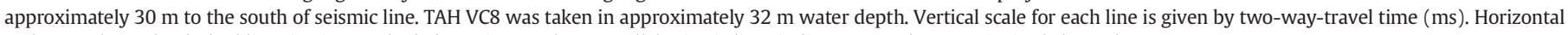
scales are shown by dashed lines in Fig. 2C. Shaded area in top, shore parallel seismic lines indicates areas between incised channels.

indentations), likely contributes to more extensive back-barrier incision there. We expect that the importance of terrestrial river incision on reef morphology gradually decreases as lagoon width increases and the volcanic upland is worn down. For example, decoupling of upland river systems and lagoonal channels propagating from barrier edge is observed in the much wider ( 10-20 km) Nouméa lagoon, New Caledonia (Le Roy et al., 2008).

The maintenance of deep channels due to lowstand incision may also be key to limiting highstand lagoon deposition, and therefore promoting empty-bucket morphology. Holocene accumulation ( $>1 \mathrm{~m} / \mathrm{kyr}$ in TAH VC9) of in-situ and wave-transported carbonates has mostly filled in the channels in Tahaa's northern lagoon (Figs. 2, 4). However, minimal accumulation has occurred in Tahaa's southern lagoon (Fig. 4), possibly due to winnowing of sediments during storms, exaggerating relief generated by lowstand dissolution/erosion. Even at depths $>30 \mathrm{mbsl}$, storm currents have often been seen to exceed a meter per second on continental shelves (Shanmugam, 2008 and refs. therein). On the Great Barrier Reef, Australia, passage of strong storms

Table 1

Radiocarbon dates from TAH VC8/9 reported in radiocarbon years. Samples dated at NOSAMS.

\begin{tabular}{lclccc}
\hline Core & Depth $(\mathrm{cm})$ & Material & $\delta^{13} \mathrm{C} \%$ & Age $\left({ }^{14} \mathrm{C}\right.$ years $)$ & Error $\left({ }^{14} \mathrm{C}\right.$ years $)$ \\
\hline VC8 & $60-61$ & Carbonate & & 1792 & 168 \\
VC8 & $161-162$ & Carbonate & & 2817 & 169 \\
VC8 & $245-246$ & Org C & -24.6 & 20,500 & 250 \\
VC8 & $245-246$ & Org C & -24.9 & 20,300 & 250 \\
VC9 & $362-364$ & Org C & -16.6 & 2980 & 30 \\
\hline
\end{tabular}

has caused large-scale erosion of the middle shelf, 22-40 mbsl, during the Holocene (Larcombe and Carter, 2004). Davis (1928) witnessed 'violent agitation' of 'milky' lagoon waters firsthand in Fiji. At Tahaa, Pai Pai pass may accommodate evacuation of sediment mobilized in the southern lagoon during storms. Water masses in the northern lagoon may be more restricted due to shallowly submerged karst features northwest of Patio. During fair weather, predominant trade winds may also drive flow across Tahaa's eastern barrier reef/flat, some of which is then evacuated out Pai Pai pass along with fine sediment. Without highstand deposition to balance the fluvial lowstand erosion/dissolution discussed above, large, deeply eroded channels have formed in Tahaa's southern lagoon as they are likely reoccupied over successive glacial cycles.

\section{Conclusions}

Tahaa provides a snapshot of how lagoonal dissolution and sedimentation patterns may be directed by upland drainage networks. Seismic and corelog stratigraphy from Tahaa's lagoon suggest that: (1) deposits alternate between lowstand oxide-/clay-rich exposure horizons and highstand carbonates; (2) the accumulation of clastic terrestrial sediment from the upland is minimal in the lagoon; (3) antecedent topography and barrier reef-lagoon width constrain lowstand fluvial down-wearing; and, (4) evacuation of fine reef-derived sediment through deep passes during storms may limit highstand lagoon deposition, further reinforcing barrier reef morphology. 


\section{Acknowledgments}

This project was supported by a Jackson School Distinguished Postdoctoral Fellowship to Michael Toomey and the WHOI Coastal Ocean Institute and Ocean and Climate Change Institute. We thank the captain and crew of the S.S.V. Robert C. Seamans and Skye Moret, Stephanie Madsen, Richard Sullivan, Phil Lane, and John Jackson for their assistance with fieldwork and laboratory analyses. We appreciated helpful feedback on this manuscript from Dan Doctor (USGS) as well as an anonymous reviewer. Any use of trade, firm, or product names is for descriptive purposes only and does not imply endorsement by the U.S. Government.

\section{References}

Andréfouët, S., Muller-Karger, F.E., Robinson, J.A., Kranenburg, C.J., Torres-Pulliza, D. Spraggins, S.A., Murch, B., 2006. Global assessment of modern coral reef extent and diversity for regional science and management applications: a view from space. Proceedings of the 10th International Coral Reef Symposium, Okinawa, Japan, pp. $1732-1745$.

Buigues, D.C., 1997. Geology and hydrogeology of Mururoa and Fangataufa, French Polynesia. In: Vacher, L.H., Quinn, T.M. (Eds.), Geology and Hydrogeology of Carbonate Islands. Elsevier, Amsterdam, pp. 433-451.

Cabioch, G., Camoin, G., Montaggioni, L., 1999. Postglacial growth history of a French Polynesian barrier reef tract, Tahiti, central Pacific. Sedimentology 46, 985-1000.

Camoin, G., Ebren, P., Eisenhauer, A., Bard, E., Faure, G., 2001. A 300,000-yr coral reef record of sea level changes, Mururoa atoll (Tuamotu archipelago, French Polynesia). Palaeogeogr. Palaeoclimatol. Palaeoecol. 175, 325-341.

Cleveland, W.S., 1979. Robust locally weighted regression and smoothing scatterplots. J. Am. Stat. Assoc. 74, 829-836.

Daly, R.A., 1910. Pleistocene glaciation and the coral reef problem. Am. J. Sci. Series 4 Vol. 30, 297-308.

Darwin, C., 1842. The Structure and Distribution of Coral Reefs: Being the First Part of the Geology of the Voyage of the Beagle, Under the Command of Capt. Fitzroy, RN During the Years 1832 to 1836. Smith, Elder and Company, London.

Dasgupta, R., Jackson, M.G., Lee, C.T.A., 2010. Major element chemistry of ocean island basalts - conditions of mantle melting and heterogeneity of mantle source. Earth Planet. Sci. Lett. 289, 377-392.

Davis, W.M., 1928. The Coral Reef Problem. American Geographical Society, New York.

Detrick, R.S., Crough, S.T., 1978. Island subsidence, hot spots, and lithospheric thinning. J. Geophys. Res. 83, 1236-1244.

Ellison, J.C., 1994. Palaeo-lake and swamp stratigraphic records of Holocene vegetation and sea-level changes, Mangaia, Cook Islands. Pac. Sci. 48, 1-15.

Gischler, E., 2011. Sedimentary facies of Bora Bora, Darwin's type barrier reef (Society Islands, South Pacific): the unexpected occurrence of non-skeletal grains. J. Sediment. Res. 81, 1-17.

Guilcher, A., 1969. Les Récifs et lagons coralliens de Mopelia et de Bora-Bora (îles de la Société): et quelques autres récifs et lagons de comparaison (Tahiti, Scilly, Tuamotu occidentales); morphologie, sédimentologie, fonctionnement hydrologique. IRD Editions.
Guillou, H., Maury, R.C., Blais, S., Cotten, J., Legendre, C., Guille, G., Caroff, M., 2005. Age progression along the Society hotspot chain (French Polynesia) based on new unspiked K-Ar ages. Bull. Soc. Géol. Fr. 176, 135-150.

Heiri, O., Lotter, A.F., Lemcke, G., 2001. Loss on ignition as a method for estimating organic and carbonate content in sediments: reproducibility and comparability of results. J. Paleolimnol. 25, 101-110.

Huppert, K.L., Royden, L.H., Perron, J.T., 2015. Dominant influence of volcanic loading on vertical motions of the Hawaiian Islands. Earth Planet. Sci. Lett. 418, 149-171.

Lambeck, K., Chappell, J., 2001. Sea level change through the last glacial cycle. Science 292, 679-686.

Larcombe, P., Carter, R., 2004. Cyclone pumping, sediment partitioning and the development of the Great Barrier Reef shelf system: a review. Quat. Sci. Rev. 23, 107-135.

Le Roy, P., Cabioch, G., Monod, B., Lagabrielle, Y., Pelletier, B., Flamand, B., 2008. Late Quaternary history of the Nouméa lagoon (New Caledonia, South West Pacific) as depicted by seismic stratigraphy and multibeam bathymetry: a modern model of tropical rimmed shelf. Palaeogeogr. Palaeoclimatol. Palaeoecol. 270, 29-45.

Ohde, S., Greaves, M., Masuzawa, T., Buckley, H.A., Van Woesik, R., Wilson, P.A., Pirazzoli, P.A., Elderfield, H., 2002. The chronology of Funafuti Atoll: revisiting an old friend. Proc. R. Soc. Lond. Ser. A Math. Phys. Eng. Sci. 458, 2289-2306.

Peterson, F.L., 1972. Water development on tropic volcanic islands - type example: Hawaii. Groundwater 10, 18-23.

Pirazzoli, P., 1985. Leeward Islands, Maupiti, Tupai, Bora Bora, Huahine, Society Archipelago. Proceedings of the 5th International Coral Reef Symposium, Tahiti, pp. 17-72.

Poppe, L.J., Paskevich, V.F., Hathaway, J.C., Blackwood, D.S., 2001. A laboratory manual for X-ray powder diffraction. U.S. Geol. Surv. Open File Rep. 1 (041), 1-88.

Purdy, E., Winterer, E., 2006. Contradicting barrier reef relationships for Darwin's evolution of reef types. Int. J. Earth Sci. 95, 143-167.

Reimer, P.J., Bard, E., Bayliss, A., Beck, J.W., Blackwell, P.G., Ramsey, C.B., Buck, C.E., Cheng, H., Edwards, R.L., Friedrich, M., 2013. IntCal13 and Marine13 radiocarbon age calibration curves 0-50,000 years cal BP. Radiocarbon 55, 1869-1887.

Roberts, M.L., von Reden, K.F., Burton, J.R., McIntyre, C.P., Beaupre, S.R., 2013. A gasaccepting ion source for accelerator mass spectrometry: progress and applications. Nucl. Instrum. Methods Phys. Res., Sect. B 294, 296-299.

Shanmugam, G., 2008. The constructive functions of tropical cyclones and tsunamis on deep-water sand deposition during sea level highstand: implications for petroleum exploration. AAPG Bull. 92, 443-471.

Stein, C.A., Stein, S., 1992. A model for the global variation in oceanic depth and heat flow with lithospheric age. Nature 359, 123-129.

Stoddart, D.R., Spencer, T., 1987. Rurutu reconsidered: the development of makatea topography in the Austral Islands. Atoll Res. Bull. 297, 1-19.

Stoddart, D.R., Spencer, T., Scoffin, T., 1985. Reef growth and karst erosion on Mangaia, Cook Islands: a reinterpretation. Z. Geomorphol. 57, 1-140.

Stuiver, M., Polach, H.A., 1977. Discussion; reporting of C-14 data. Radiocarbon 19, 355-363.

Taborosi, D., Jenson, J.W., Mylroie, J.E., 2005. Karst features of Guam, Mariana Islands. Micronesica 38, 17-46.

Toomey, M.R., Donnelly, J.P., Woodruff, J.D., 2013. Reconstructing mid-late Holocene cyclone variability in the Central Pacific using sedimentary records from Tahaa, French Polynesia. Quat. Sci. Rev. 77, 181-189.

Wardlaw, B.R., Quinn, T.M., 1991. The record of Pliocene sea-level change at Enewetak Atoll. Quat. Sci. Rev. 10, 247-258.

Zinke, J., Reijmer, J.J.G., Thomassin, B.A., 2001. Seismic architecture and sediment distribution within the Holocene barrier reef lagoon complex of Mayotte (Comoro archipelago, SW Indian Ocean). Palaeogeogr. Palaeoclimatol. Palaeoecol. 175, 343-368. 